\title{
SAP Scientia Agraria Paranaensis
}

Scientia Agraria Paranaensis - Sci. Agrar. Parana.

ISSN: 1983-1471 - Online

\section{HEIGHT, VOLUME AND FORM FACTOR EQUATIONS FOR Tectona grandis L.f. IN ALTA FLORESTA (MT)}

\author{
Adriana Coimbra de Morais ${ }^{1}$, Thelma Shirlen Soares ${ }^{1 *}$, Edmilson Santos Cruz ${ }^{1}$ \\ SAP 21548 Received: 17/01/2019 Accepted: 23/03/2019 \\ Sci. Agrar. Parana., Marechal Cândido Rondon, v. 19, n. 1, jan./mar., p. 27-37, 2020
}

\begin{abstract}
Studies on allometric models are essential for quantifying the potential of a stand, especially when the objective is to know the wood stock through estimates. This study aimed to select height, volume and artificial form factor equations for a teak stand with data from a sample with 81 trees at 96 months in different diameter classes. The correlation analysis was performed between the variables total height, diameter with and without bark at $1.30 \mathrm{~m}$ soil height $\left(\mathrm{dbh}_{\mathrm{cc}}\right.$ and $\left.\mathrm{dbh}_{\mathrm{sc}}\right)$, total volume with and without bark $\left(\mathrm{VT}_{\mathrm{cc}}\right.$ and $\left.\mathrm{VT}_{\mathrm{sc}}\right)$ and artificial form factor with and without bark ( $\mathrm{ff}_{\mathrm{cc}}$ and $\left.\mathrm{ff}_{\mathrm{sc}}\right)$, using the Pearson coefficient. Six models were evaluated for each category: height, volume and artificial form factor, which were selected by the following criteria: analysis of variance, adjusted coefficient of determination, standard error of estimate, Akaike information criterion and graphical analysis of residues. The selected equations were validated by applying the $\mathrm{L} \& \mathrm{O}$ test. The variables $\mathrm{dbh}_{\mathrm{cc}}, \mathrm{dbh}_{\mathrm{sc}}, \mathrm{HT}, \mathrm{VT}_{\mathrm{cc}}$ and $\mathrm{VT}_{\mathrm{sc}}$ presented significant correlations, ranging from moderate to very strong, the others presented weak correlation. The model that presented the best relation of total height to diameter was the model of Azevedo and contributors. For the total volume with and without bark, Schumacher and Hall model in its logarithmic form was the one that presented the best results. The adjusted models for artificial form factor did not present satisfactory results and, therefore, the use of average form factor is recommended. The mean form factor values by diameter class ranged from 0.4498 to 0.7139 and 0.4480 to 0.7075 for diameter with and without bark, respectively.
\end{abstract}

Keywords: teak, hypsometric relationship, volumetric models.

\section{EQUAÇÕES DE ALTURA, VOLUME E FATOR DE FORMA PARA Tectona grandis L.f. EM ALTA FLORESTA (MT)}

\begin{abstract}
RESUMO - Estudos sobre modelos alométricos são essenciais para a quantificação do potencial de um povoamento, principalmente quando o objetivo é conhecer o estoque de madeira por meio de estimativas. Diante do exposto, este estudo teve como objetivo selecionar equações de altura, volume e fator de forma artificial para um povoamento de teca sendo empregados dados de uma amostra com 81 árvores com 96 meses em diferentes classes de diâmetro. Foi realizada a análise de correlação entre altura total, diâmetro com e sem casca a 1,30 m de altura do solo $\left(\right.$ dap $_{\mathrm{cc}}$ e $\left.d a p_{\mathrm{sc}}\right)$, volume total com e sem casca $\left(\mathrm{VT}_{\mathrm{cc}}\right.$ e $\mathrm{VT}_{\mathrm{sc}}$ ) e fator de forma artificial com e sem casca $\left(\mathrm{ff}_{\mathrm{cc}}\right.$ e $\mathrm{ff}_{\mathrm{sc}}$ ), utilizando o coeficiente de Pearson. Foram avaliados seis modelos para cada categoria: altura, volume e fator de forma artificial os quais foram selecionados pelos critérios: análise de variância, coeficiente de determinação ajustado, erro padrão da estimativa, critério de informação Akaike corrigido e análise gráfica de resíduos. As equações selecionadas foram validadas pela aplicação do teste de L\&O. As variáveis dap $_{\mathrm{cc}}$, dap $_{\mathrm{sc}}$, HT, $\mathrm{VT}_{\mathrm{cc}}$ e $\mathrm{VT}_{\mathrm{sc}}$ apresentaram correlações significativas que variaram de moderadas a muito fortes, as demais apresentaram correlação fraca. O modelo que apresentou melhor relação da altura total com o diâmetro foi o modelo de Azevedo e colaboradores. Para volume total com e sem casca, o modelo de Schumacher e Hall na forma logarítmica foi o que apresentou os melhores resultados. Os modelos ajustados para fator de forma artificial não apresentaram resultados satisfatórios sendo, portanto, recomendado o uso de fator de forma médio. Os fatores de forma médios calculados por classe diamétrica variaram de 0,4498 a 0,7139 e 0,4480 a 0,7075 para diâmetros com e sem casca, respectivamente.
\end{abstract}

Palavras-chave: teca, relações hipsométricas, modelos volumétricos.

\section{INTRODUCTION}

Forests planted in Brazil occupy 7.84 million hectares and are responsible for more than $91 \%$ of all the wood used for productive purposes, in addition to contributing to the conservation of biodiversity, soil preservation, regulation of water resources, recovery of degraded areas and generation of renewable energy (IBÁ, 2018).
As an alternative to minimize the impact of wood consumption from native forests, these planted forests have been used and, in their majority, they consist of species of the genera Eucalyptus and Pinus (MOTTA et al., 2016). However, other species have been successfully introduced, with emphasis on Tectona grandis L.f., known as teak (CERQUEIRA et al., 2017). 
Teak is a species from the Asian continent, cultivated in several regions of Africa and the Americas (PELISSARI et al., 2014). The factors related to the interest in the species are the high demand and international valorization of its wood, in addition to its high durability (PELISSARI et al., 2013; SANQUETTA et al., 2015), good stability, resistance and aesthetic qualities of its wood, which makes it possible to use it in sophisticated sectors, such as luxury furniture, shipbuilding, high-quality frames and the production of plywood and laminates (TONINI et al., 2009; BARROS et al., 2017). Other related factors are the reduction in wood supply by the countries of Southwest Asia, the increase in restrictive measures against illegal logging and import restrictions (SCHUHLI and PALUDZYSYN FILHO, 2010).

Height is a variable that can be considered difficult to measure when compared to diameter (ALMEIDA et al., 2016) since it can be obtained directly or indirectly and, in certain cases, mainly in stands whose individuals are at more advanced ages, due to canopy closing and lack of visibility at the top, the measurement can result in error and high cost (MOTTA et al., 2016).

Due to these operational and economic difficulties in obtaining all heights, hypsometric equations are commonly used in forest inventories (ROSSI et al., 2011; MENDONÇA et al., 2015; MOTTA et al., 2016), reducing costs and the time spent in carrying out the forest inventory (SANQUETTA et al., 2014a).

The hypsometric relationship expresses the relationship between the height of the tree and its respective diameter at $1.30 \mathrm{~m}$ from ground height (dbh). Through linear and non-linear regression, mathematical models are tested and equations are generated to obtain height estimates (SANQUETTA et al., 2014b).

To estimate the volumetric production of a forest stand, the use of volumetric equations and form factors can be highlighted (NUNES and SOARES, 2017). Volumetric equations have the real volume as a dependent variable, obtained by rigorous cubing and, as independent variables, $\mathrm{dbh}$ and total height. However, there is a need to test several volumetric equations to identify the best equation for each situation, since some models do not show satisfactory results for all forest species or for all edaphoclimatic conditions in each region (MACHADO et al., 2002; ALMEIDA et al., 2016).

For volume estimation, volumetric models are frequently used. However, in the impossibility of their use, it is possible to use form factors, which are factors that reduce the volume of the cylinder to the actual volume of the tree obtained through cubing (MIRANDA et al., 2015).

According to Prodan et al. (1997), the form factor can be classified into two types: real or true and false or artificial, based on the height of the reference diameter measurement point. Thus, the form factor is real or true $\left(\mathrm{f}_{0.1}\right)$ when the diameter is measured at $10 \%$ shaft height and false or artificial $\left(f_{1.3}\right)$ when the diameter is measured at $1.30 \mathrm{~m}$ from the ground.

The determination of the form factor is essential for the estimation of the artificial volume of trees (DRESCHER et al., 2001) and, in order to be expressed, measurable factors, such as diameter, height and canopy size are used (PRODAN et al., 1997). In this context, this study aimed to select equations to estimate total height, total volume with and without bark and artificial form factor with and without bark for a Tectona grandis stand.

\section{MATERIAL AND METHODS}

Data from a teak reforestation area implanted in the municipality of Alta Floresta, in the Northern region of the State of Mato Grosso, Brazil, located at $10^{\circ} 02$ '51'S and $56^{\circ} 20^{\prime} 18^{\prime \prime} \mathrm{W}$, were used.

The climate of the region is characterized by two seasons, a dry season (from May to September) and a rainy season (from October to April). The average annual temperature is between 24 and $26{ }^{\circ} \mathrm{C}$, with a maximum average of $38^{\circ} \mathrm{C}$ (BRASIL, 1980) and the average annual rainfall is $2700 \mathrm{~mm}$. The soils consist mainly of RedYellow Dystrophic Argisol.

For the adjustment of mathematical relations, 81 sample trees aged 96 months in different diameter classes and in different locations were rigorously cubed, according to the Smalian method, as a function of terrain heterogeneity (site), for the obtention of heights, diameters and actual volumes (Table 1). The selected trees were felled and trunk diameter was measured, with and without bark.

TABLE 1 - Frequency distribution of sample trees used to adjust the models for a teak stand in Alta Floresta (MT).

\begin{tabular}{|c|c|c|c|c|c|c|}
\hline \multirow{2}{*}{$\begin{array}{l}\text { Diametric class } \\
(\mathrm{cm})\end{array}$} & \multicolumn{5}{|c|}{ Height class (m) } & \multirow{2}{*}{ Total } \\
\hline & $6.0-9.0$ & $9.0-12.0$ & $12.0-15.0$ & $15.0-18.0$ & $18.0-21.0$ & \\
\hline $6.0 \dashv 9.0$ & & & 1 & & & 1 \\
\hline $9.0 \dashv 12.0$ & & & 1 & 3 & & 4 \\
\hline $12.0 \dashv 15.0$ & & & 2 & 9 & & 11 \\
\hline $15.0 \dashv 18.0$ & & & 2 & 16 & & 18 \\
\hline $18.0 \dashv 22.0$ & & 10 & 12 & 19 & 1 & 42 \\
\hline $22.0 \dashv 25.0$ & 1 & 1 & 3 & & & 5 \\
\hline Total & 1 & 11 & 21 & 47 & 1 & 81 \\
\hline
\end{tabular}

For the adjustment of the artificial form factor models, the values of the individual form factor were required for each sample tree, which was calculated by the ratio between the volume of the cylinder (obtained from the basal area of the tree at $1.30 \mathrm{~m}$ from the ground and the 
tree height) and the actual volume of the tree (obtained by rigorous cubing).

Correlation analysis was performed between the variables total height, dbh (with and without bark), total volume (with and without bark) and artificial form factor (with and without bark) using the Pearson coefficient $(r)$, which determines the degree of association between two variables.

The values obtained were evaluated using the criteria proposed by Callegari-Jacquer (2003): correlation,
- If: $|0.30| \leq r<|0.60|=$ there is a moderate linear correlation, correlation,

- If: $|0.60| \leq r<|0.90|=$ there is a strong linear linear correlation.

The models adjusted for total height, total volume (with and without bark) and artificial form factor (with and without bark) are presented in Tables 2, 3, and 4, respectively.

TABLE 2 - Models tested to estimate the total height of individual trees for a teak stand in Alta Floresta (MT).

\begin{tabular}{llr}
\hline Number & \multicolumn{1}{c}{ Model } & \multicolumn{1}{c}{ Authors } \\
\hline 1 & $\ln (\mathrm{HT})=\beta_{0}+\beta_{1} \ln (d b h)+\varepsilon_{\mathrm{i}}$ & Stoffel and Soest (1953) \\
2 & $\ln (\mathrm{HT})=\beta_{0}+\beta_{1} d b h^{-1}+\varepsilon_{\mathrm{i}}$ & Curtis $(1967)$ \\
3 & $\ln (\mathrm{HT})=\beta_{0}+\beta_{1} d b h+\beta_{2} d b h^{2}+\varepsilon_{\mathrm{i}}$ & Parabolic logarithmic \\
4 & $\ln (\mathrm{HT})=\beta_{0}+\beta_{1} d b h^{-1}+\beta_{2} \ln (d b h)+\varepsilon_{\mathrm{i}}$ & Not identified \\
5 & $\mathrm{HT}=\beta_{0}+\beta_{1} d b h+\beta_{2} d b h^{2}+\varepsilon_{\mathrm{i}}$ & Parabolic \\
6 & $\mathrm{HT}=\left(d b h /\left(\beta_{0}+\beta 1 / d b h+\beta_{2} d b h^{2}\right)\right)^{2}+\varepsilon_{\mathrm{i}}$ & Azevedo et al. $(2011)$ \\
\hline
\end{tabular}

Where: $\ln =$ neperian logarithm; HT = total height $(\mathrm{m}) ; d b h=$ diameter at breast height at $1.30 \mathrm{~m}$ above the ground $(\mathrm{cm}) ; \beta_{0}, \beta_{1}$, $\beta_{2}=$ parameters to be estimated; $\varepsilon_{i}=$ random error, $\varepsilon \mathrm{i} \sim \operatorname{NID}\left(0, \sigma^{2}\right)$.

TABLE 3 - Models tested to estimate the total volume of individual trees for a teak stand in Alta Floresta (MT).

\begin{tabular}{llr}
\hline Number & \multicolumn{1}{c}{ Model } & \multicolumn{1}{c}{ Authors } \\
\hline 1 & $\ln (\mathrm{VT})=\beta_{0}+\beta_{1} \ln (d b h)+\beta_{2} \ln (\mathrm{HT})+\varepsilon_{\mathrm{i}}$ & Schumacher and Hall (1933) \\
2 & $\mathrm{VT}=\beta_{0}+\beta_{1} d b h+\beta_{2} d b h^{2}+\beta_{3} d b h \mathrm{HT}+\beta_{4} d b h^{2} \mathrm{HT}+\varepsilon_{\mathrm{i}}$ & Meyer (1946) modified \\
3 & $\ln (\mathrm{VT})=\beta_{0}+\beta_{1} \ln \left(d b h^{2} \mathrm{HT}\right)+\varepsilon_{\mathrm{i}}$ & Spurr (1952) \\
4 & $\mathrm{VT}=\beta_{0}+\beta_{1} d b h^{2}+\beta_{2} d b h^{2} \mathrm{HT}+\beta_{3} \mathrm{HT}+\varepsilon_{\mathrm{i}}$ & Stoate (1945) \\
5 & $\mathrm{VT}=\beta_{0}+\beta 1 d b h^{2} \mathrm{HT}+\varepsilon_{\mathrm{i}}$ & Spurr $(1952)$ \\
6 & $\mathrm{VT}=\beta_{0} d b h^{\beta 1} \mathrm{HT}^{\beta 2}+\varepsilon_{\mathrm{i}}$ & Schumacher and Hall (1933) \\
\hline
\end{tabular}

Where: $\ln =$ neperian logarithm; VT $=$ total volume $\left(\mathrm{m}^{3}\right) ; d b h=$ diameter at breast height at $1.30 \mathrm{~m}$ above the ground $(\mathrm{cm})$; $\mathrm{HT}=$ total height $(\mathrm{m}) ; \beta_{0}, \beta_{1}, \beta_{2}, \beta_{3}, \beta_{4}=$ parameters to be estimated; $\varepsilon_{\mathrm{i}}=$ random error, $\varepsilon \mathrm{i} \sim \mathrm{NID}\left(0, \sigma^{2}\right)$.

TABLE 4 - Models tested to estimate the artificial form factor of individual trees for a teak stand in Alta Floresta (MT).

\begin{tabular}{llr}
\hline Number & \multicolumn{1}{c}{ Model } & Authors \\
\hline 1 & $f f=\beta_{0}+\beta_{1} d b h+\beta_{2} d b h^{2}+\varepsilon_{\mathrm{i}}$ & Not identified \\
2 & $f f=\beta_{0}+\beta_{1}\left(1 / d b h^{2} \mathrm{HT}\right)+\beta_{2} 1 / \mathrm{HT}+\beta_{3} 1 / d b h^{2}+\varepsilon_{\mathrm{i}}$ & Not identified \\
3 & $f f=\beta_{0}+\beta_{1}\left(1 / d b h^{2} \mathrm{HT}\right)+\beta_{2}(1 / d b h \mathrm{HT})+\beta_{3} 1 / d b h+\beta_{4} 1 / \mathrm{HT}+\varepsilon_{\mathrm{i}}$ & Not identified \\
4 & $f f=\beta_{0}+\beta_{1} 1 / \mathrm{HT}+\beta_{2} \mathrm{~h} / d b h+\beta_{3} \mathrm{~h} / d b h^{2}+\varepsilon_{\mathrm{i}}$ & Not identified \\
5 & $f f=\beta_{0}+\beta_{1} 1 / d b h^{2}+\beta_{2} \mathrm{HT} / d b h^{2}+\beta_{3} 1 / \mathrm{HT}+\beta_{4} 1 / d b h+\varepsilon_{\mathrm{i}}$ & Not identified \\
6 & $f f=\beta_{0}+\beta_{1} \mathrm{HT} / d b h+\beta_{2} 1 / \mathrm{HT}+\varepsilon_{\mathrm{i}}$ & Not identified \\
\hline
\end{tabular}

Where: $\ln =$ neperian logarithm; $f f=$ artificial form factor; $d b h=$ diameter at breast height at $1.30 \mathrm{~m}$ above the ground $(\mathrm{cm})$; $\mathrm{HT}=$ total height $(\mathrm{m}) ; \beta_{0}, \beta_{1}, \beta_{2}, \beta_{3}, \beta_{4}=$ parameters to be estimated; $\varepsilon_{\mathrm{i}}=$ random error, $\varepsilon \mathrm{i} \sim \mathrm{NID}\left(0, \sigma^{2}\right)$.

The adjusted models were evaluated and the selection of the best equation to obtain the estimates of total height, total volume and artificial form factor was based on the following criteria: analysis of variance $(\mathrm{F})$, adjusted determination coefficient $\left(\mathrm{R}^{2}{ }_{\mathrm{aj}}\right)$, standard error of the percentage estimate $\left(\mathrm{S}_{\mathrm{yx}} \%\right)$, corrected Akaike information criterion (AICc) and graphical analysis of the residues.

The analysis of variance $(F)$ is obtained by the ratio between the variance of the model or the regression and the variance of the error and is used to check if there is a significant difference between the means and if the factors have any influence on the dependent variable.
When several models are adjusted, the higher the "F" value, the better the performance of the equation generated by it.

The adjusted determination coefficient $\left(\mathrm{R}^{\mathbf{2}}{ }_{\mathrm{aj}}\right)$ expresses the amount of total variation explained by the regression. The closer to one the values of the determination coefficients, the better the adjustment of the regression line. The mathematical expression used to obtain $\mathrm{R}_{\text {aj }}$ is given as follows: 
Height, volume and...

$$
R^{2} a j=1-\frac{(n-1)}{(n-p)} *\left(1-R^{2}\right)
$$

Where:

$R^{2}=$ determination coefficient,

$n=$ number of sample observations,

$p=$ number of parameters of the regression model.

The standard error of the estimate $\left(\mathrm{S}_{\mathrm{yx}}\right)$ indicates the accuracy of the mathematical model adjustment and should only be used as a comparator when the dependent variables have the same unit of measurement. The smaller the standard error of the estimate, the better the estimates obtained from the equation. The standard error of the estimate is obtained by:

$$
S_{y x}=\sqrt{M E S}
$$

Where:

$M E S=$ mean error square.

With the standard error of the estimate $\left(S_{\mathrm{yx}}\right)$, standard errors of the percentage estimate $\left(\mathrm{S}_{\mathrm{yx} \%}\right)$ were calculated:

$$
S_{y x \%}=\frac{S_{y x}}{\bar{Y}} * 100
$$

Where:

$\bar{Y}=$ mean of the dependent variable.

In order to make it possible to compare logarithmic and non-logarithmic models, the logarithmic discrepancy in the estimation of the dependent variable was corrected by the Meyer correction factor (FM):

$$
F M=e^{0,5 * M E S}
$$

Where:

$\mathrm{e}=$ base of natural logarithm.

Moser e Oliveira (2017) state that the corrected Akaike information criterion $\left(\mathrm{AIC}_{\mathrm{c}}\right)$ is based on Information Theory, reflecting the loss of information associated with the predictions of a model and the observed values. Thus, the lower the value of the AIC, the more explanatory the model is. The $\mathrm{AIC}_{\mathrm{c}}$ is obtained by the expression:

$$
A I C c=[n * \ln (S S E)]-[n * \ln (n)]+2 p+\frac{2 p(p+1)}{n-p-1}
$$

Where:

$\mathrm{SSE}=$ sum of squared error, $n=$ number of sample observations,

$$
p=\text { number of parameters of the model. }
$$

The graphical analysis of residues makes it possible to verify the adjustment of the equation over data amplitude, allowing to detect possible biases in the estimates. In order to meet this assumption, the residues were plotted, as a percentage, of the estimates of the variables of interest on the dbh variable, which allowed the visualization of the behavior of these residues along the axis, selecting the model that presented the lowest residue variation.

After the selection of the equations that presented the best results, the validity of the estimates was verified by applying the L\&O test, proposed by Leite and Oliveira (2002), whose procedures result in the combination of the $\mathrm{F}\left(\mathrm{FH}_{0}\right)$ Graybill test, from the $\mathrm{t}$ test for the average error $(\mathrm{t}-\overline{\mathrm{e}})$ and the linear correlation analysis between the observed $\left(\mathrm{Y}_{\mathrm{j}}\right)$ and the estimated values $\left(\mathrm{Y}_{1}\right)$. The test compares the observed value as a dependent variable and the estimated value as an independent variable. Thus, for situations in which $\mathrm{F}\left(\mathrm{H}_{0}\right)$ and the $\mathrm{t}$ test are non-significant and the correlation is greater than $1-|\bar{e}|$, it is concluded that the values estimated by the regression do not differ from the observed values.

\section{RESULTS AND DISCUSSION}

The results of the Pearson correlation analysis for the variables dbh (with and without bark), total height, total volume (with and without bark) and artificial form factor (with and without bark) are shown in Table 5.

Table 6 shows the results pertinent to the adjustments of the hypsometric models, with the respective statistical parameters of precision and, in Figure 1, the graphic distribution of residues.

The adjusted equations presented adjusted determination coefficients that varied from 55.9 to $75.2 \%$ and standard errors of the estimate that varied from \pm 10.2 to $\pm 10.4 \%$. The equation that best fitted the data set came from model 6 (AZEVEDO et al., 2011). When evaluating the graphic distribution of residues, it was observed that the dispersion was similar in both models; thus, they do not represent a significant difference.

When working with adjustment of hypsometric models for teak trees aged 12 years, in Mojú (PA), Pereira et al. (2014), also selected model 6 (AZEVEDO et al., 2011) as being more suitable for estimating total teak height. Sanquetta et al. (2015) analyzed hypsometric models to estimate the total height of young teak individuals in a plantation located in Redenção (PA) and selected model 3 (logarithmic parabolic) in its nonlogarithmic form as the most precise and accurate for total height estimation. On the other hand, Cerqueira et al. (2017) evaluated hypsometric models in the Northeastern mesoregion of the State of Pará in 10-year-old teak stands, and recommended model 1 (Stoffel and Soest), since it presents greater adjustment accuracy. 
TABLE 5 - Correlation between the variables dbh with and without bark, total height, total volume with and without bark and artificial form factor with and without bark at 5\% significance for a teak stand in Alta Floresta (MT).

\begin{tabular}{|c|c|c|c|c|c|c|c|c|c|}
\hline & Mean & $\begin{array}{l}\text { Standard } \\
\text { deviation }\end{array}$ & $d b h_{\mathrm{cc}}$ & $d b h_{\mathrm{sc}}$ & HT & $\mathrm{VT}_{\mathrm{cc}}$ & $\mathrm{VT}_{\mathrm{sc}}$ & $f f_{\mathrm{cc}}$ & $f f_{\mathrm{sc}}$ \\
\hline$d b h_{\mathrm{cc}}$ & 18.58 & 3.09 & 1 & 1.00 & 0.50 & 0.94 & 0.94 & -0.34 & -0.34 \\
\hline$d b h_{\mathrm{sc}}$ & 18.40 & 3.08 & $*$ & 1 & 0.50 & 0.94 & 0.94 & -0.34 & -0.34 \\
\hline HT & 15.51 & 1.99 & $*$ & $*$ & 1 & 0.57 & 0.57 & -0.56 & -0.55 \\
\hline $\mathrm{VT}_{\mathrm{cc}}$ & 0.21 & 0.07 & $*$ & * & $*$ & 1 & 1.00 & -0.16 & -0.16 \\
\hline $\mathrm{VT}_{\mathrm{sc}}$ & 0.20 & 0.07 & $*$ & $*$ & $*$ & $*$ & 1 & -0.16 & -0.16 \\
\hline$f f_{\mathrm{cc}}$ & 0.48 & 0.06 & $*$ & $*$ & $*$ & $*$ & $*$ & 1 & 1.00 \\
\hline$f f_{\mathrm{sc}}$ & 0.48 & 0.06 & $*$ & $*$ & $*$ & $*$ & $*$ & $*$ & 1.00 \\
\hline
\end{tabular}

Where: $d b h_{\mathrm{cc}}=$ diameter with bark at breast height at $1.30 \mathrm{~m}$ above the ground, $d b h_{\mathrm{sc}}=$ diameter without bark at breast height at $1.30 \mathrm{~m}$ above the ground, $\mathrm{HT}=$ total height, $\mathrm{VT}_{\mathrm{cc}}=$ volume with bark, $\mathrm{VT}_{\mathrm{sc}}=$ volume without bark, $f f_{\mathrm{cc}}=$ artificial form factor with bark, $f f_{\mathrm{sc}}=$ artificial form factor without bark, $*=$ significantly to the level of $5 \%$ probability, ns $=$ not significantly to the level of $5 \%$ probability.

TABLE 6 - Regression coefficients and statistical parameters of hypsometric models adjusted for a teak stand in Alta Floresta (MT).

\begin{tabular}{|c|c|c|c|c|c|c|c|}
\hline \multirow{2}{*}{ Number } & \multicolumn{3}{|c|}{ Coefficients } & \multirow{2}{*}{$\mathrm{R}^{2}{ }_{\mathrm{aj}}(\%)$} & \multirow{2}{*}{$\mathrm{S}_{\mathrm{yx}}(\%)$} & \multirow{2}{*}{$\mathrm{F}$} & \multirow{2}{*}{$\mathrm{AIC}_{\mathrm{c}}$} \\
\hline & $\beta_{0}$ & $\beta_{1}$ & $\beta_{2}$ & & & & \\
\hline 1 & 0.8342 & 0.6394 & - & 61.0 & 10.4 & $126.33 *$ & -338.61 \\
\hline 2 & 3.1834 & -8.8178 & - & 63.4 & 10.2 & $139.39 *$ & -343.43 \\
\hline 3 & 1.1886 & 0.1379 & -0.0030 & 61.3 & 10.4 & $64.49 *$ & -338.07 \\
\hline 4 & 2.9116 & -7.8309 & 0.0746 & 62.9 & 10.2 & $68.93 *$ & -341.35 \\
\hline 5 & -0.3254 & 1.2625 & -0.0232 & 55.9 & 10.2 & $51.77^{*}$ & 69.21 \\
\hline 6 & -3.6697 & 9.1849 & -0.0046 & 75.2 & 10.3 & $176.92 *$ & 70.20 \\
\hline
\end{tabular}

Where: $\beta_{\mathrm{i}}=$ regression coefficient, $\mathrm{R}_{\mathrm{aj}}^{2} \%=$ adjusted determination coefficient, $\mathrm{S}_{\mathrm{yx}}=$ standard error of the estimate, $\mathrm{F}=$ analysis of variance, $\mathrm{AIC}_{\mathrm{c}}=$ corrected Akaike information criterion, $*$ significantly at $5 \%$ probability.

[1]

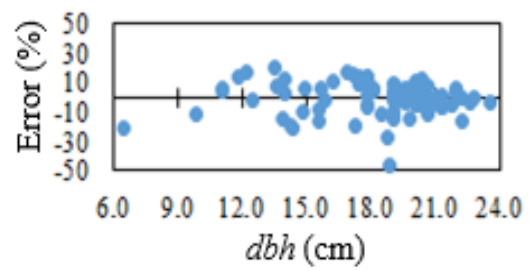

[4]

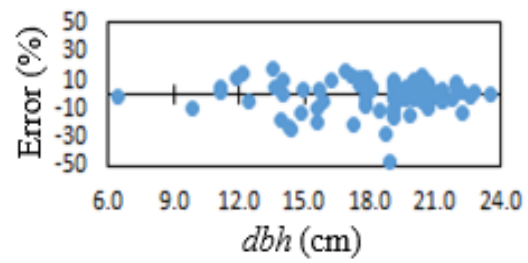

[2]

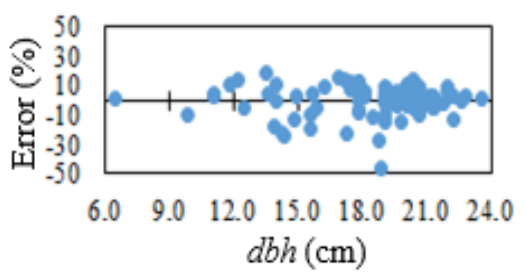

[5]

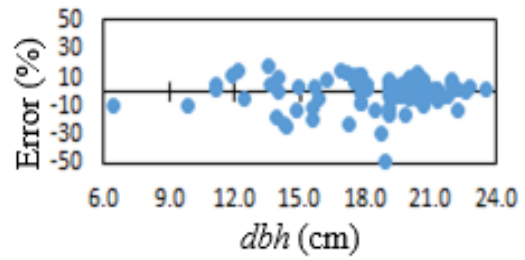

[3]

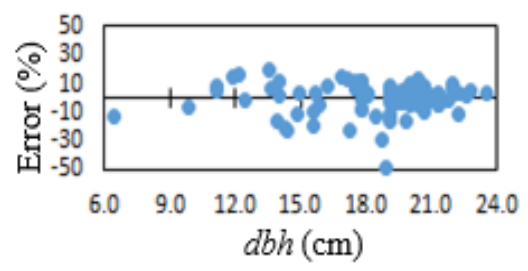

[6]

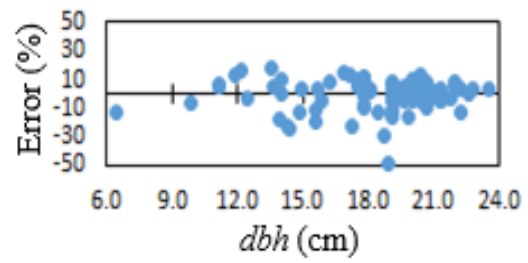

FIGURE 1 - Graphical distribution of residues of hypsometric equations adjusted for a teak stand in Alta Floresta (MT), Where: [1] = Stoffel and Stoate, [2] = Curtis, [3] = parabolic logarithmic, [4] = unidentified author, [5] = parabolic, [6] = Azevedo et al.

In Tables 7 and 8 , the results related to the adjustments of the volumetric models are represented, with the respective statistical precision parameters and, in
Figures 2 and 3, the graphic distributions of residues, for data with and without bark, respectively. 
TABLE 7 - Regression coefficients and statistical parameters of volumetric with bark models adjusted for a teak stand in Alta Floresta (MT).

\begin{tabular}{|c|c|c|c|c|c|c|c|c|c|}
\hline \multirow{2}{*}{ Number } & \multicolumn{5}{|c|}{ Coefficients } & \multirow[b]{2}{*}{$\mathrm{R}^{2}{ }_{\mathrm{aj}}(\%)$} & \multirow{2}{*}{$\begin{array}{c}\mathrm{S}_{\mathrm{yx}} \\
(\%)\end{array}$} & \multirow{2}{*}{$\mathrm{F}$} & \multirow{2}{*}{$\mathrm{AIC}_{\mathrm{c}}$} \\
\hline & $\beta_{0}$ & $\beta_{1}$ & $\beta_{2}$ & $\beta_{3}$ & $\beta_{4}$ & & & & \\
\hline 1 & -9.0807 & 1.9230 & 0.6685 & - & - & 97.1 & \pm 9.6 & $1359.1 *$ & -372.1 \\
\hline 2 & -0.1292 & 0.0309 & -0.0012 & -0.0010 & 0.0000 & 93.9 & \pm 9.1 & $309.8 *$ & -622.2 \\
\hline 3 & -9.1997 & 0.8827 & - & - & - & 97.0 & \pm 9.4 & $2555.0 *$ & -368.6 \\
\hline 4 & 0.0010 & 0.0001 & 0.0000 & -0.0010 & - & 93.7 & \pm 9.6 & $394.8 *$ & -620.2 \\
\hline 5 & 0.0174 & 0.0000 & - & - & - & 93.7 & \pm 9.5 & $1198.2 *$ & -623.6 \\
\hline 6 & 0.0001 & 1.8020 & 0.8324 & - & - & 96.1 & \pm 9.4 & $3464.2 *$ & -622.5 \\
\hline
\end{tabular}

Where: $\beta_{\mathrm{i}}=$ regression coefficient, $\mathrm{R}_{\mathrm{aj}}^{2} \%=$ adjusted determination coefficient, $\mathrm{S}_{\mathrm{yx}}=$ standard error of the estimate, $\mathrm{F}=$ analysis of variance, $\mathrm{AIC}_{\mathrm{c}}=$ corrected Akaike information criterion, $*=$ significantly at $5 \%$ probability.

[1]

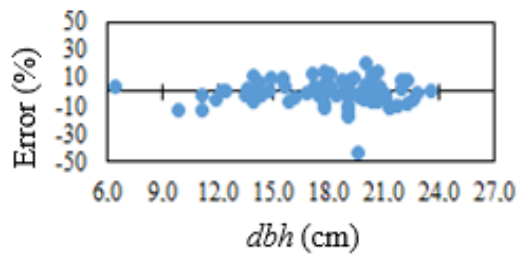

[4]

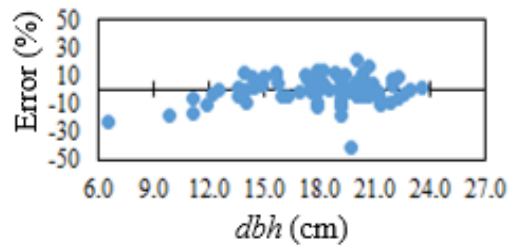

[2]

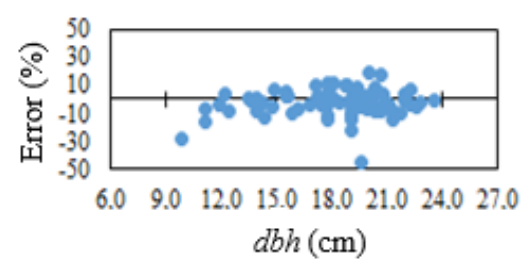

[5]

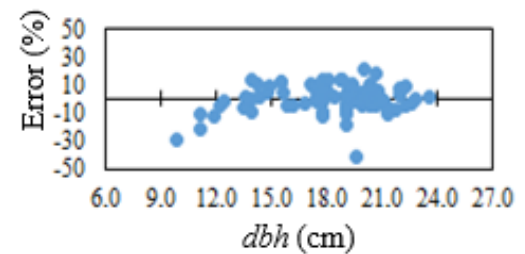

[3]

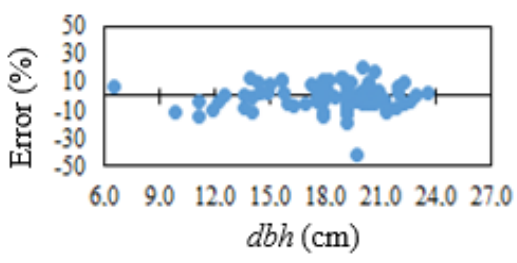

[6]

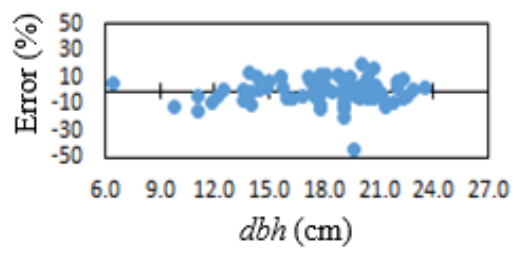

FIGURE 2 - Graphical distribution of residues of volumetric with bark equations adjusted for a teak stand in Alta Floresta (MT). Where: [1] = Schumacher and Hall (log), [2] = Meyer modified, [3] = Spurr logaritmic, [4] = Stoate, [5] = Spurr, [6] $=$ Schumacher and Hall.

TABLE 8 - Regression coefficients and statistical parameters of volumetric without bark models adjusted for a teak stand in Alta Floresta (MT).

\begin{tabular}{|c|c|c|c|c|c|c|c|c|c|}
\hline \multirow{2}{*}{ Number } & \multicolumn{5}{|c|}{ Coefficients } & \multirow{2}{*}{$\mathrm{R}^{2}{ }_{\mathrm{aj}}(\%)$} & \multirow{2}{*}{$\mathrm{S}_{\mathrm{yx}}(\%)$} & \multirow{2}{*}{$\mathrm{F}$} & \multirow{2}{*}{$\mathrm{AIC}_{\mathrm{c}}$} \\
\hline & $\beta_{0}$ & $\beta_{1}$ & $\beta_{2}$ & $\beta_{3}$ & $\beta_{4}$ & & & & \\
\hline 1 & -9.0869 & 1.9220 & 0.6705 & - & - & 97.1 & \pm 9.6 & $1358.6^{*}$ & -370.9 \\
\hline 2 & -0.1253 & 0.0304 & -0.0012 & -0.0010 & 0.0001 & 93.9 & \pm 9.3 & $310.8 *$ & -625.4 \\
\hline 3 & -9.2114 & 0.8894 & - & - & - & 97.0 & \pm 10.8 & $2259.1 *$ & -367.6 \\
\hline 4 & 0.0002 & 0.0001 & 0.0000 & 0.0010 & - & 93.7 & \pm 9.6 & $395.8^{*}$ & -623.3 \\
\hline 5 & 0.0172 & 0.0000 & - & - & - & 93.7 & \pm 9.5 & $1200.9 *$ & -626.6 \\
\hline 6 & 0.0001 & 1.7969 & 0.8345 & - & - & 96.9 & \pm 9.4 & $3447.0 *$ & -625.7 \\
\hline
\end{tabular}

Where: $\beta_{\mathrm{i}}=$ regression coefficient, $\mathrm{R}_{\mathrm{aj}}^{2} \%=$ adjusted determination coefficient, $\mathrm{S}_{\mathrm{yx}}=$ standard error of the estimate, $\mathrm{F}=$ analysis of variance, $\mathrm{AIC}_{\mathrm{c}}=$ corrected Akaike information criterion, $*=$ significantly at $5 \%$ probability. 
[1]

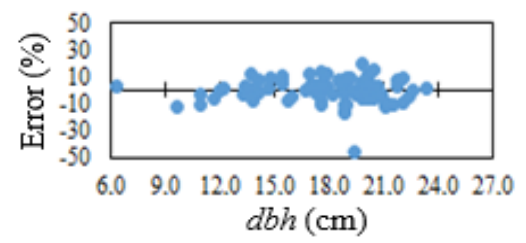

[4]

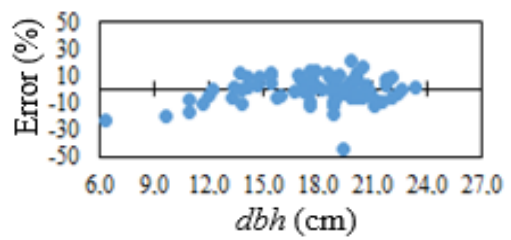

[2]

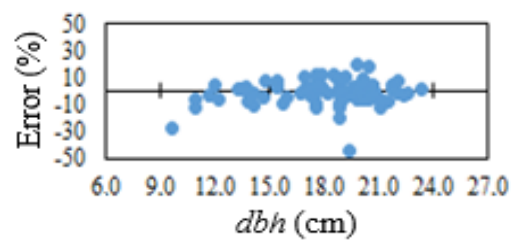

$[5]$

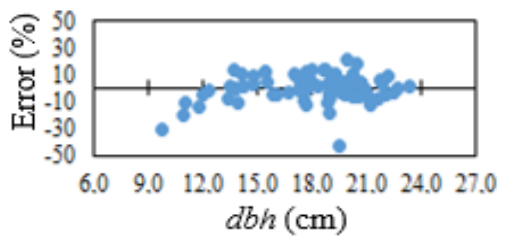

[3]

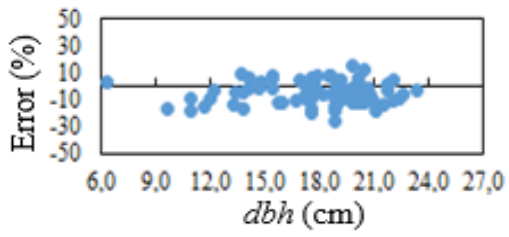

[6]

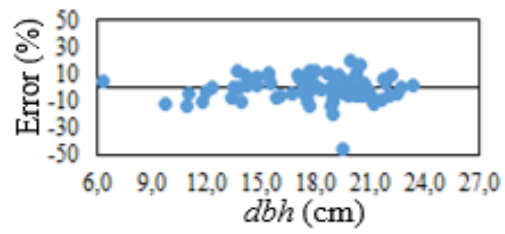

FIGURE 3 - Graphical distribution of residues of volumetric without bark equations adjusted for a teak stand in Alta Floresta (MT). Where: $[1]=$ Schumacher and Hall $(\log )$, [2] = Meyer modified, [3] = Spurr logaritmic, [4] = Stoate, [5] = Spurr, [6] = Schumacher and Hall.

The values of the adjusted determination coefficient obtained by adjusting the volumetric models for values of dbh with and without bark had the same variation, 93.7 to $97.1 \%$. The standard error values of the estimate with and without bark ranged from $\pm 9.1 \%$ to $\pm 9.6 \%$ and from $\pm 9.3 \%$ to $\pm 10.8 \%$, respectively.

Taking into account all the selection criteria for the equations, the one that best fitted the database under study, with and without bark, was model 1 (Schumacher and Hall in its logarithmic form).
Tonini et al. (2009), Drescher et al. (2014) and Almeida et al. (2016) selected volumetric models for teak stands, and also obtained better results for the Schumacher and Hall model in its logarithmic form.

In Tables 9 and 10, the results related to the adjustments of the artificial factor models are represented, with the respective precision statistical parameters and, in Figures 4 and 5, the graphic distributions of residues, for data with and without bark, respectively.

TABLE 9 - Regression coefficients and statistical parameters of artificial form factor with bark models adjusted for a teak stand in Alta Floresta (MT).

\begin{tabular}{|c|c|c|c|c|c|c|c|c|c|}
\hline \multirow{2}{*}{ Number } & \multicolumn{5}{|c|}{ Coefficients } & \multirow[b]{2}{*}{$\mathrm{R}^{2}{ }_{\mathrm{aj}}(\%)$} & \multirow[b]{2}{*}{$\mathrm{S}_{\mathrm{yx}}(\%)$} & \multirow{2}{*}{$\mathrm{F}$} & \multirow{2}{*}{$\mathrm{AIC}_{\mathrm{c}}$} \\
\hline & $\beta_{0}$ & $\beta_{1}$ & $\beta_{2}$ & $\beta_{3}$ & $\beta_{4}$ & & & & \\
\hline 1 & 0.7693 & 0.0244 & 0.0005 & - & - & 31.5 & \pm 9.6 & $19.1 *$ & -472.9 \\
\hline 2 & 0.2982 & -11.5649 & 2.8577 & 1.4727 & - & 45.1 & \pm 8.6 & $22.9 *$ & -489.3 \\
\hline 3 & 0.2772 & 4.0723 & -4.6116 & 0.5596 & 2.7166 & 44.5 & \pm 8.6 & $17.1 *$ & -487.2 \\
\hline 4 & -0.2268 & 6.1523 & 0.5982 & -4.4440 & - & 49.5 & \pm 8.2 & $27.1 *$ & -495.8 \\
\hline 5 & 0.2575 & -6.6186 & -2.1672 & 1.0516 & 4.8343 & 45.1 & \pm 8.6 & $17.4^{*}$ & -437.3 \\
\hline 6 & 0.2806 & 0.0284 & 2.5328 & - & - & 46.1 & \pm 8.5 & $35.2 *$ & -491.9 \\
\hline
\end{tabular}

Where: $\beta_{\mathrm{i}}=$ regression coefficient, $\mathrm{R}_{\mathrm{aj}}^{2} \%=$ adjusted determination coefficient, $\mathrm{S}_{\mathrm{yx}}=$ standard error of the estimate, $\mathrm{F}=$ analysis of variance, $\mathrm{AIC}_{\mathrm{c}}=$ corrected Akaike information criterion, $*=$ significantly at $5 \%$ probability. 
$[1]$

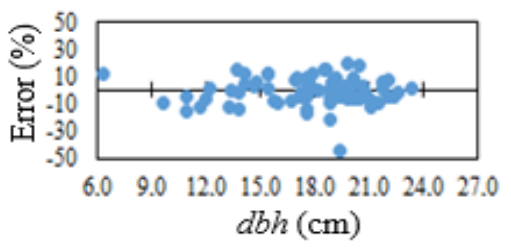

[4]

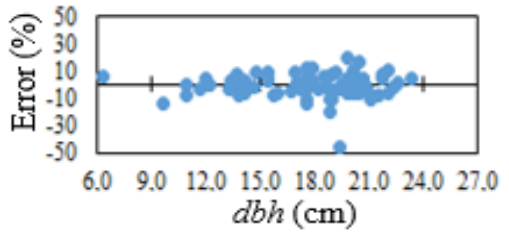

[2]

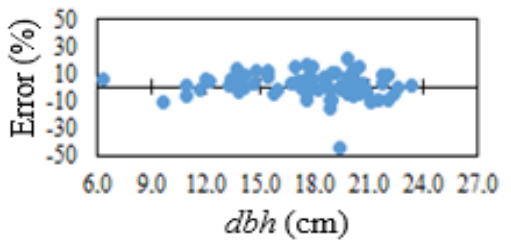

[5]

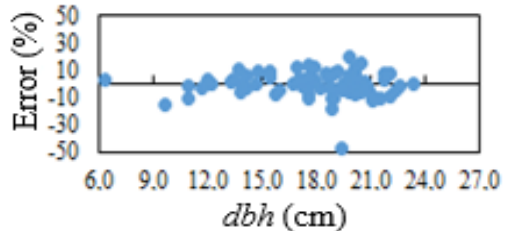

[3]

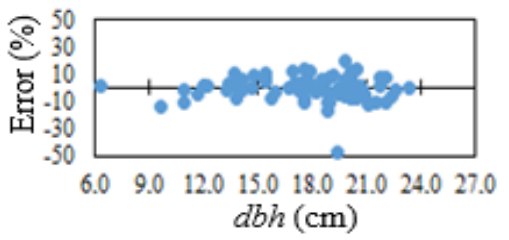

[6]

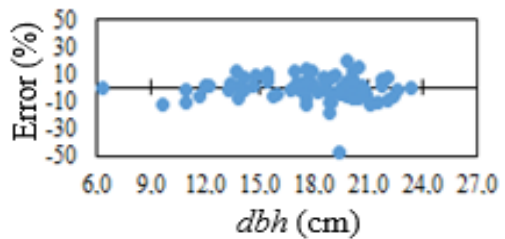

FIGURE 4 - Graphical distribution of residues of artificial form factor with bark equations adjusted for a teak stand in Alta Floresta (MT).

TABLE 10 - Regression coefficients and statistical parameters of artificial form factor without bark models adjusted for a teak stand in Alta Floresta (MT).

\begin{tabular}{|c|c|c|c|c|c|c|c|c|c|}
\hline \multirow{2}{*}{ Number } & \multicolumn{5}{|c|}{ Coefficients } & \multirow{2}{*}{$\mathrm{R}^{2}{ }_{\text {aj }}(\%)$} & \multirow{2}{*}{$\mathrm{S}_{\mathrm{yx}}(\%)$} & \multirow{2}{*}{$\mathrm{F}$} & \multirow{2}{*}{$\mathrm{AIC}_{\mathrm{c}}$} \\
\hline & $\beta_{0}$ & $\beta_{1}$ & $\beta_{2}$ & $\beta_{3}$ & $\beta_{4}$ & & & & \\
\hline 1 & 0.7553 & -0.0232 & 0.0004 & - & - & 31.0 & \pm 9.6 & $19.0 *$ & -473.0 \\
\hline 2 & 0.2875 & -12.5735 & 2.6576 & 0.2022 & - & 44.7 & \pm 8.8 & $22.5 *$ & -489.0 \\
\hline 3 & 0.2785 & -5.46582 & -2.5863 & 0.5115 & 2.6291 & 44.0 & \pm 8.7 & $16.7^{*}$ & -486.8 \\
\hline 4 & -0.2239 & 6.1173 & 0.5865 & -4.2945 & - & 49.1 & \pm 8.3 & $26.7 *$ & -495.5 \\
\hline 5 & 0.2524 & -7.1267 & -2.2453 & 0.9579 & 5.1055 & 44.7 & \pm 8.6 & $17.1 *$ & -487.7 \\
\hline 6 & 0.2805 & 0.0284 & 2.5098 & - & - & 45.5 & \pm 8.6 & $34.4 *$ & -491.4 \\
\hline
\end{tabular}

Where: $\beta_{\mathrm{i}}=$ regression coefficient, $\mathrm{R}_{\mathrm{aj}}^{2} \%=$ adjusted determination coefficient, $\mathrm{S}_{\mathrm{yx}}=$ standard error of the estimate, $\mathrm{F}=$ analysis of variance, $\mathrm{AIC}_{\mathrm{c}}=$ corrected Akaike information criterion, $*=$ significantly at $5 \%$ probability.

The results of determination coefficient adjusted for form factor equations with and without bark varied from $31.5 \%$ to $49.5 \%$ and $31.0 \%$ to $49.1 \%$ respectively. The standard error values of the estimate ranged from $\pm 8.2 \%$ to $\pm 9.6 \%$ and $\pm 8.3 \%$ to $\pm 9.6 \%$ for data with and without bark, respectively. When evaluating the graphic distribution of residues, it was observed that the dispersion was similar in both models, not representing significant differences.
When adjusting artificial factor models for a young teak stand in Mato Grosso, Drescher et al. (2010) found values of adjusted determination coefficient and standard error of the estimate of $98.6 \%$ and $\pm 12.7 \%$ for model 6, respectively. Both et al. (2011) adjusted artificial form factor models for teak in Monte Dourado (PA), and found values similar to those found by Drescher et al. (2010). 
[1]

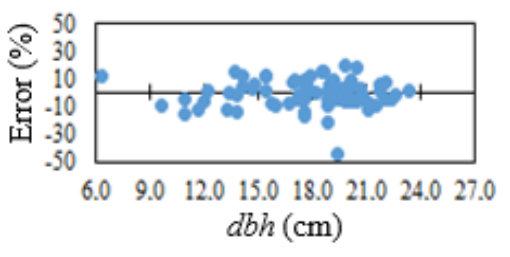

[4]

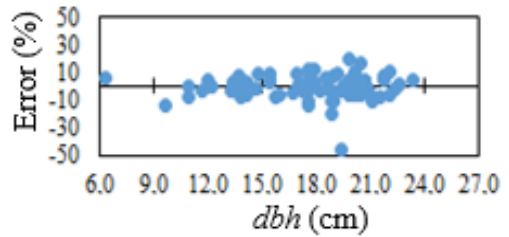

[2]

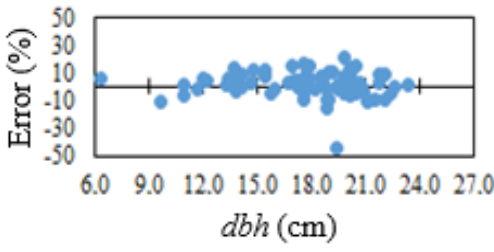

[ग]

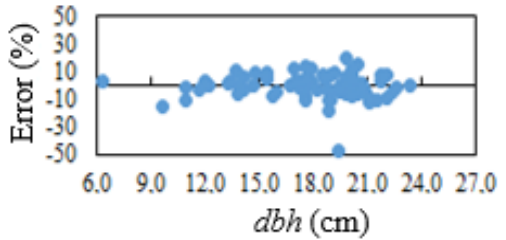

[3]

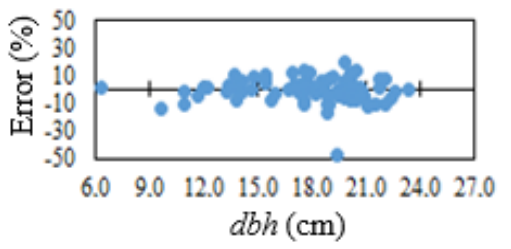

[6]

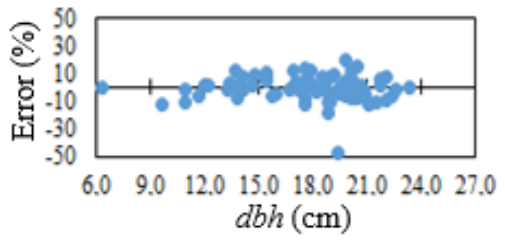

FIGURE 5 - Graphical distribution of residues of artificial form factor without bark equations adjusted for a teak stand in Alta Floresta (MT).

Considering that the determination coefficient expresses how much the independent variables account for the variations of the dependent variable, that is, how much the equation fits data reality, models that present values below $50 \%$ are not satisfactory for the studied data.

These results are probably due to the low results presented by the adjustments, due to the low correlation of the dependent variable (artificial form factor with and without bark) with the independent variables (dbh with and without bark and total height). It is worth mentioning that, in addition to the models presented, other models proposed by Drescher et al. (2001), Drescher et al. (2010) and Correia et al. (2017) were tested; however, the results were lower than those presented.

Considering the results obtained in this study, the use of these artificial form factor models is not recommended, but the use of the medium form factor. Thus, the average form factors were calculated for each diametric class and are shown in Table 11.

TABLE 11 - Mean artificial form factor with and without bark by diametric class for a teak stand in Alta Floresta (MT).

\begin{tabular}{lrr}
\hline $\mathrm{Ll} \dashv \mathrm{Lu}$ & Mean artificial form factor with bark & Mean artificial form factor with bark \\
\hline $6.0 \dashv 9.0$ & 0.7139 & 0.7075 \\
$9.0 \dashv 12.0$ & 0.5023 & 0.5008 \\
$12.0 \dashv 15.0$ & 0.5256 & 0.5246 \\
$15.0 \dashv 18.0$ & 0.4882 & 0.4871 \\
$18.0 \dashv 22.0$ & 0.4646 & 0.4631 \\
$22.0 \dashv 25.0$ & 0.4498 & 0.4480 \\
\hline Mean & 0.4822 & 0.4807 \\
\hline
\end{tabular}

Where: $\mathrm{Ll}=$ lower limit, $\mathrm{Lu}=$ upper limit.

The values of the average form factors calculated by diametric class ranged from 0.4498 to 0.7139 for data with bark and 0.4480 to 0.7075 for data without bark, and are in accordance with results found in the literature.

In a teak reforestation area in the Northern Amazon, Tonini et al. (2009) found an average form factor of 0.56, while Figueiredo et al. (2005) found average form factor values of 0.61 for trees up to 4 years old, 0.52 for trees between 5 and 7 years old and 0.48 for trees of 8 and 9 years old, for a young teak stand in Rio Branco and Acrelância, both municipalities in Acre.
Table 12 shows the results of the L\&O test for the selected equations for estimating the total height, total volume with and without bark and artificial form factor with and without bark. Through the statistical procedure proposed by Leite and Oliveira (2002), the $\mathrm{H}_{0}$ hypothesis was accepted, as it was found that the estimates obtained by the hipsometric and volumetric equations without bark, were statistically equal to the values of total height and total volume observed with and without bark. 
Height, volume and...

MORAIS, A. C. et al. (2020)

TABLE 12 - Statistics of the L\&O test for validation of the selected equations for a teak stand in Alta Floresta (MT).

\begin{tabular}{|c|c|c|c|c|c|}
\hline \multirow{2}{*}{ Variable } & \multirow{2}{*}{ Equation } & \multicolumn{3}{|c|}{ L\&O Test } & \multirow{2}{*}{ Conclusion } \\
\hline & & $\mathrm{F}\left(\mathrm{H}_{0}\right)$ & $\mathrm{t}_{\overline{\mathrm{e}}}$ & $\mathrm{r}_{\mathrm{yj}} \mathrm{r}_{\mathrm{yi}} \geq|1-\overline{\mathrm{e}}|$ & \\
\hline HT & 6 & $0.00^{\mathrm{ns}}$ & $0.83^{\mathrm{ns}}$ & Sim & $\mathrm{Y}_{\mathrm{j}}$ is statistically equal to $\mathrm{Y} 1$ \\
\hline $\mathrm{VT}_{\mathrm{cc}}$ & 6 & $0.03^{\mathrm{ns}}$ & $1.06^{\mathrm{ns}}$ & Sim & $\mathrm{Y}_{\mathrm{j}}$ is statistically equal to $\mathrm{Y}_{1}$ \\
\hline $\mathrm{VT}_{\mathrm{sc}}$ & 6 & $0.71^{\mathrm{ns}}$ & $0.66^{\mathrm{ns}}$ & Sim & $Y_{j}$ is statistically equal to $Y_{1}$ \\
\hline$f f_{\mathrm{cc}}$ & 4 & $3.68 *$ & $0.69^{\mathrm{ns}}$ & Sim & $Y_{j}$ is statistically different to $Y_{1}$ \\
\hline$f f_{\mathrm{sc}}$ & 4 & $3.64 *$ & $0.68^{\mathrm{ns}}$ & Sim & $\mathrm{Y}_{\mathrm{j}}$ is statistically different to $\mathrm{Y}_{1}$ \\
\hline
\end{tabular}

Where: $\mathrm{HT}=$ total height, $\mathrm{VT}_{\mathrm{cc}}=$ total volume with bark, $\mathrm{VT}_{\mathrm{sc}}=$ total volume without bark, $f f_{\mathrm{cc}}=$ artificial form factor with bark, $f f_{\mathrm{sc}}=$ artificial form factor without bark, $\mathrm{Y}_{\mathrm{j}}=$ observed values, $\mathrm{Y}_{1}=$ estimated values, $*=$ significantly to the level of 5\% probability, $\mathrm{ns}=$ not significantly to the level of $5 \%$ probability.

For the estimates obtained by the artificial form factor equations, for data with and without bark, using the statistical procedure proposed by the $\mathrm{L} \& \mathrm{O}$ test, the $\mathrm{H}_{0}$ hypothesis was rejected, as it was found that they differ statistically from the observed values. The rejection of the $\mathrm{H}_{0}$ hypothesis may be related to the low correlation of the form factor with the independent variables.

\section{CONCLUSIONS}

The hypsometric equation generated by the model $\mathrm{H}=(d b h /(-4.5909+19.5976 / d b h-0.0036 d b h))^{2}$, presented greater precision to estimate total height.

For total volume with and without bark, the equation for diameters with bark: $\ln (\mathrm{VT})=-9.0807+$ $1.9230 \ln (d b h)+0.6685 \ln (\mathrm{HT})$ and diameters without bark: $\ln (\mathrm{VT})=-9.0869+1.9220 \ln (d b h)+0.6705 \ln (\mathrm{HT})$, both from the Schumacher and Hall model in its logarithmic form, showed greater precision.

The models adjusted for artificial form factor did not present satisfactory results. Therefore, the use of medium form factor is recommended. The average form factors calculated by diametric class ranged from 0.4498 to 0.7139 and 0.4480 to 0.7075 for diameters with and without bark, respectively.

\section{REFERENCES}

ALMEIDA, D.L.C.S.; SILVA, F.R.; SANTOS, A.F.A.; GARCIA, M.L.; WOJCIECHOWSKI, J.C. Determinação de equação volumétrica e hipsométrica para um plantio de Tectona grandis L. F. em Alta Floresta, MT. Ciência Agroambientais, v.14, n.2, p.1-9, 2016.

AZEVEDO, G.B.; SOUSA, G.T.O.; SILVA, H.F.; BARRETO, P.A.B.; NOVAES, A.B. Seleção de modelos hipsométricos para quatro espécies florestais nativas em plantio misto no Planalto da Conquista na Bahia. Enciclopédia Biosfera, v.7, n.12, p.1-13, 2011.

BARROS, K.L.C.; MACEDO, R.L.G.; VENTURIN, N. Capacidade de brotação de teca sob regime de talhadia composta. Floresta e Ambiente, v.24, e00134315, 2017. BOTH, I.W.; CARVALHO, T.G.; DRESCHER, R. Determinação de fator de forma artificial para Tectona grandis Linn F. em povoamento equiâneo situado em Monte Dourado, estado do Pará, Brasil. Multitemas, v.1, n.40, p.61-74, 2011.
BRASIL. Departamento Nacional da Produção Mineral. Levantamento de recursos naturais. Folha SC. 21. Juruena; geologia, geomorfologia, pedologia, vegetação e uso do potencial da terra. Rio de Janeiro: Gráfica Alvorada Ltda., 1980.

CALLEGARI-JACQUES, S.M. Bioestatística: princípios e aplicações. Porto Alegre: Artmed, 2003. 264p.

CERQUEIRA, C.L.; LISBOA, G.S.; FRANÇA, C.J.; MÔRA, R.; MARQUES, G.M.; SALLES, T.T.; BRIANEZI, D. Modelagem de altura e volume de Tectona grandis L. f. na mesorregião Nordeste do Pará. Nativa, v.5, n.esp., p.606-611, 2017.

CORREIA, J.; FANTINI, A.; PIAZZA, G. Equações volumétricas e fator de forma e de casca para florestas secundárias do Litoral de Santa Catarina. Floresta e Ambiente, v.24, n.1, p.1-12, 2017.

CURTIS, R.O. Height diameter and height age equations for second growth Douglas-fir. Forest Science, v.13, n.4, p.365-375, 1967.

DRESCHER, R.; GAVA, F.H.; PELISSARI, A.L.; ACOSTA, F.C.; SILVA, V.S.M. Equações volumétricas para Tectona grandis Linn F. em povoamentos jovens no estado de Mato Grosso. Advances in Forestry Science, v.1, n.2, p.65-70, 2014.

DRESCHER, R.; PELISSARI, A.L.; GAVA, F.H. Fator de forma artificial para povoamentos jovens de Tectona grandis em Mato Grosso. Pesquisa Florestal Brasileira, v.30, n.63, p.191-197, 2010.

DRESCHER, R.; SCHNEIDER, P.R.; FINGER, C.A.G.; QUEIROZ, F.L.C. Fator de forma artificial de Pinus elliottii Engelm para a região da serra do sudoeste do Estado do Rio Grande do Sul. Ciência Rural, v.31, n.1, p.37-42, 2001.

FIGUEIREDO, E.; SCOLFORO, J.R.S.; OLIVEIRA, A.D. Estimativa do percentual de casca e fator de forma em povoamentos jovens de teca (Tectona grandis L.f.). Rio Branco: Embrapa Acre, 2005. 5p. (Comunicado Técnico, 165).

IBÁ. INDÚSTRIA BRASILEIRA DE ÁRVORES. Relatório IBÁ 2017. São Paulo: Estúdio 113, 2018. 80p. LEITE, H.G.; OLIVEIRA, F.H.T. Statistical procedure to test the identity of analytical methods. Communications in Soil Science and Plant Analysis, v.33, n.7-8, p.1105-1118, 2002. 
MACHADO, S.A.; CONCEIÇÃO, M.B.; FIGUEIREDO, J. Modelagem do volume individual para diferentes idades e regime de desbaste em plantações de Pinus oocarpa. Ciências Exatas e Naturais, v.4, n.2, p.185-197, 2002. MENDONÇA, A.R.; CARVALHO, P.C.; CALEGARIO, N. Modelos hipsométricos generalizados mistos na predição da altura de Eucalyptus sp. Cerne, v.21, n.1, p.107-115, 2015.

MEYER, H.A. Bark volume determination in trees. Journal Foresty, v.44, n.2, p.1067-1070, 1946.

MIRANDA, D.L.C.; BERNARDINO JUNIOR, V.; GOUVEIA, D.M. Fator de fora e equações de volume para estimativa volumétrica de árvores em plantio de Eucalyptus urograndis. Scientia Plena, v.11, n.3, p.1-8, 2015.

MOSER, P.; OLIVEIRA, L.Z. Regressão linear aplicada à dendrometria: uma introdução e iniciação à linguagem R. Blumenau: Edifurb, 2017. 152p.

MOTTA, A.S.; ALMEIDA, E.J.; VENDRUSCOLO, D.G.S.; SOUSA, H.S.; MEDEIROS, R.A.; SILVA, R.S. Modelagem da altura de Tectona grandis L. f. clonal e seminal. Revista Brasileira de Biometria, v.34, n.3, p.395-406, 2016.

NUNES, J.S.; SOARES, T.S. Estimativa volumétricas para um povoamento adensado de Eucalyptus $s p$. em regime de curta rotação. Revista Agricultura Neotropical, v.4, n.4, p.77-86, 2017.

PELISSARI, A.L.; CALDEIRA, S.F.; DRESCHER, R. Desenvolvimento quantitativo e qualitativo de Tectona grandis L. f. em Mato Grosso. Floresta e Ambiente, v.20, n.3, p.371-383, 2013.

PELISSARI, A.L.; GUIMARÃES, P.P.; BEHLING, A.; EBLING, Â.A. Cultivo da teca: caracteristicas da espécie para implantação e condução de povoamentos florestais. Agrarian Academy, v.1, n.1, p.127-145, 2014.

PEREIRA, K.D; PAIXÃO, M.V.C.; MONTEIRO, C.W.B.; LAURIDO, F.T.; FERREIRA, P.S.T. Ajuste d modelos hipsométricos para árvores de Tectona grandis L.f. no município de Mojú, Pará. Enciclopédia Biosfera, v.10, n.18, p.181-189, 2014.

PRODAN, M.; PETERS, R.; COX, F.; REAL, P. Mensura florestal. San José, Costa Rica: IICA, 1997. 586p.

ROSSI, A.S.; DRESCHER, R.; PELISSARI, A.L.; LANSSANOVA, L.R. Relação hipsométrica e cerscimento de Tectona grandis L. f. no município de Monte Dourado, Pará. Scientia Florestalis, v.39, n.91, p.301-307, 2011.

SANQUETTA, C.R.; BEHLING, A.; CORTE, A.P.D.; RUZA, M.S.; SÃO JOSÉ, J.F.B. Relação hipsométrica em inventário pré-corte em povoamentos de Acacia mearnsii de Wild. Científica, v.42, n.1, p.80-90, 2014a.

SANQUETTA, M.N.I.; SANQUETTA, C.R.; MOGNON, F.; CORTE, A.P.D.; MONASTIER, S.H. Equações hipsométricas para obtenção de comprimento de colmo para Phyllostachys aurea Carr. ex A. \& C. Rivi're. Enciclopédia Biosfera, v.10, n.19, p.990-997, 2014b.
SANQUETTA, M.N.I.; SANQUETTA, C.R.; MOGNON, F.; CORTE, A.P.D.; RODRIGUES, A.L.; MAAS, G.C.B. Ajuste de equações hipsométricas para a estimação da altura total de indivíduos jovens de teca. Científica, v.43, n.4, p.400-406, 2015.

SCHUHLI, S.E.; PALUDZYSZYN FILHO, E. Cenário da silvicultura de teca e perspectivas para o melhoramento genético. Pesquisa Florestal Brasileira, v.30, n.63, p.217-230, 2010.

SCHUMACHER, F.X.; HALL, F.S. Logarithmic expression. Of timber-tree volume. Journal of Agricultural Research, v.47, n.9, p.719-734, 1933.

SPURR, S.H. Forest inventory. New York: Ronald Press, 1952. 476p

STOATE, I.N. The use of a volume equation in pine stands. Australian Forestry, v.9, [s.n.], p.48-52, 1945.

STOFFEL, A.; SOEST, J.V. Principiële vraagstukken bij proefperken. Nederlands Bosbouw Tijdschrift, v.25, [s.n.], p.190-199, 1953.

TONINI, H.; COSTA, M.C.G.; SCHWENGBER, L.A.M. Crescimento de teca (Tectona grandis) em reflorestamento na Amazônia Setentrional. Pesquisa Florestal Brasileira, v.5, n.59, p.5-14, 2009. 